\title{
Intangible Cultural Heritage and Tourism: Comparing Croatia and the Czech Republic
}

\section{Sonja Lovrentjev}

\author{
University of Rijeka, Faculty of Tourism and Hospitality Management, Primorska 42, p.p. 97, 51410 Opatija, Croatia
}

Email: sonja.lovrentjev@gmail.com

\author{
Doi:10.5901/mjss.2015.v6n5s1p522
}

\begin{abstract}
This paper describes the importance of cultural heritage in tourism. It examines possible positive effects of engaging elements of intangible cultural heritage (ICH) in the supply of tourist destination on sustainable development and economic growth of tourism. The paper sets up the framework for the comprehensive research analysis and compares the cases of Croatia and the Czech Republic with regard to the UNESCO site and the intangible cultural heritage. It employs the definition and consecutive discussion of seven main postulates related to the determinants and outcomes of the ICH. Moreover, it reports the result of the pilot survey and sets up the framework for the larger data collection and analysis.
\end{abstract}

Keywords: intangible cultural heritage, tourism, sustainable development, Croatia, Czech Republic

\section{Introduction}

International tourism has become one of the fastest-growing industries in the world. According to World Tourist Organization (WTO), the number of tourist arrivals is 2014 surpassed 1,087 million (WTO, 2015). Tourism is considered to be the largest industry in the world, based on the contribution to the gross domestic product (GDP) (see Rodzi et al., 2013; or Herget et al., 2014), and is associated with many important challenges of the $21^{\text {st }}$ century, such as infectious diseases (see Strielkowski, 2014).

The most visited region in the world is Europe with around 563 million tourist arrivals per each year. Europe is a leading region mostly because of its historical background and its cultural heritage. Cultural heritage is an integral part of almost all tourist travels, of course in different extent of attractiveness per each tourist itself. In the last century, different organizations stood up for safeguarding heritage and preventing it from devastation caused by multiple influences including tourism. The United Nations Educational, Scientific and Cultural Organization (UNESCO) have put afford to gather, present and preserve heritage, tangible and intangible, worldwide.

This paper is structured as follows: Section 2 describes the role of sustainable development in tourism. Section 3 outlines the importance of $\mathrm{ICH}$ in tourism promotion and tourism-related activities. Section 4 provides a brief comparison of Croatia and the Czech Republic from the point of view of UNESCO heritage sites, their tourism promotion and their potential for the ICH development. Finally, section 5 concludes the paper with some final remarks and policy implications.

\section{Sustainable Development and Tourism}

World Tourism Organisation (WTO) defined sustainable tourism as „tourism that takes full account of its current and future economic, social and environmental impacts, addressing the needs of visitors, the industry, the environment and host communities"(WTO, 2005). Sustainable development of tourism is an approach, recognised at an international level that should outcome with benefits at economic, environmental and social level in all types of tourism (Lazano-Oyola et al., 2012). Among authors it is agreed that managing tourism in a sustainable way, based on principles of sustainable development can bring long term advancement in experience for visitors and rise quality of life for local community (Bramwell and Lane, 1993; Choi and Sirakaya, 2006; or Chiabai et al., 2014). Sustainable tourism development principles could be used in all forms of tourism in all types of destinations, from the various types of tourism to the mass tourism. Moreover, those principles are applicable, with certain modifications regarding the unique specifics of destination or type of tourism. (Sharareh and Budaruddin, 2013). When it comes to intangible cultural heritage, preservation might be endangered if the development of tourism gives priority to the satisfaction of tourists instead of giving priority to the maintenance of traditional values in the local municipality (Coccossis, 2008). As mentioned before, there are three dimensions of sustainability and it is proposed that tourist valorisation of intangible cultural heritage could contribute to 
sustainable development of (cultural) tourism. Its benefits should be observable in economic and social dimension on the local community while rising tourist satisfaction.

\section{Intangible Cultural Heritage and Tourism}

In the context of cultural heritage, two segments can be differed: tangible and intangible cultural heritage. Our focus will be intangible cultural heritage and its use in tourism with emphasise on sustainable development of cultural tourism. Referring to United Nations Educational, Scientific and Cultural Organization (UNESCO) intangible cultural heritage (ICH) can be defined as oral traditions, performing arts, social practices, rituals, festive events, knowledge and practices concerning nature and the universe or the knowledge and skills to produce traditional crafts (see Kurin, 2004). In tourism, both tangible and intangible cultural heritage have been used as a tourist assets. Heritage contribution in tourism development is based on the capitalization of cultural resources (Leask and Rihova, 2010). According to authors this can be achieved, among the rest, through developing heritage tourism policies and products that meet the needs of all important stakeholders: community, policymakers and tourists. Sustainable development of heritage tourism should pay attention to stakeholder's communication and improve it among all included parties. Furthermore, they should participate in the process of creation of the authentic and individual visitor experiences.

Studying cultural heritage, especially intangible, discussion about authenticity cannot be avoided. Authors take different approaches to define authenticity in tourism: objective, constructive and existential authenticity. Objectivism approach is based on determination of the true nature of objects by experts and emphasise genuine, real and honest not "staged" performance of heritage (Wang, 1999). Constructive approach states that things appear authentic because they are invention based on tradition (Hughes, 1995). For the existentialists, authenticity means to exist according to nature or essence (Steiner and Reisinger, 2006). Zhu (2012) concludes that authenticity depends on personal memory, constructed identity and the complexity of the contemporary by participating or witnessing of manifestation of local culture. However in this research, authenticity of cultural goods will be implied and will not be examined.

Engaging element of intangible cultural heritage in tourism offer, or, in other words, their tourist valorisation, could bring multiple benefits to the sustainable development of tourism. In order to examine the effects and contribution of intangible cultural heritage on sustainable development of tourism one can offer several postulates that can be discussed in detail.

The first postulate is that tourist valorisation of $\mathrm{ICH}$ contributes to the development of complementary tourist products and/or activities. The main idea behind this premise is that no tourist product can stand alone by itself. Even in case of mass tourism, where 3s (sun, sea, and sand) are the main attractiveness for tourists other elements of tourist offer must arise. Accommodation units, restaurants, bars, shops are supplementing the tourist experience. In case of cultural goods, base assumption is that tourist are motivated by culture, at some certain extent. If the intangible cultural heritage will be recognised by tourist it may become one of the reasons for visiting the destination. This may not be suitable for well-established tourist destinations but in case of small uprising destinations ICH can take part in development. This postulate should contribute to the economic and indirectly to socio-cultural dimension of sustainability.

The second postulate assumes that formation of cultural/tourist product of $\mathrm{ICH}$ brings higher revenues to the local community. Creation of product implies intention to market the outcome. $\mathrm{ICH}$ can be performed in tourist purposes as a demonstration of traditional production procedure. Moreover, workshops can be made and tourists may take part in them. For that kind of experience tourist would pay. This statement might contribute to the economic dimension of sustainability.

The third postulate states that tourist valorisation of $\mathrm{ICH}$ contributed to higher employment in the local community. The causation is quite simple and straightforward: as the tourist demand is rising, the need for employment is rising as well. It is assumed that in case of intangible cultural heritage, considering the heritage belongs to the local community, employees will be residents.

The first three postulates can be tested using secondary data and verifying the assumptions based on the gathered data and their analysis. Interviews will be conducted with representatives of local community, owners of shops, breweries, restaurants and other complementary activities or products. Also, the statistic information about the revenue, employment and taxes will be examined.

The fourth postulate implies that tourist valorization of $\mathrm{ICH}$ increases tourist spending. The reasoning is quite straightforward: intangible cultural heritage has to be formed in some type of product in order to be put on the tourist market. Cultural product in this case can be presentation, demonstration or a souvenir based on intangible cultural good. Tourists that are interested will participate in workshops and be willing to pay for that kind of experience. Moreover, souvenir that is produced using traditional production method will have higher value. Tourist will spend more money in the destination consuming intangible cultural heritage. 
The fifth postulate says that tourist valorization of $\mathrm{ICH}$ contributes to the prolongation of tourist stay. It is assumed that well established intangible cultural heritage will contribute to prolonging the stay. Some tourists have fixed dates of arrival and departure, especially one traveling by plane and in that case prolongation is not possible. On the other hand, some tourists are coming to visit the region and not just the destination. They are staying for a longer time in the region and have ability to modify the micro plan of their travel. If possible, tourist will modify their stay in order to experience something new, different and special for the destination. That will bring another value to their tourist experience.

The sixth postulate states that tourism-related valorization of $\mathrm{ICH}$ attracts tourists out of the high season. Seasonality is one of the main concerns in tourism development. Some destinations have a very specific period of high season. That applies mostly to the destinations with one dominant attractive factor. Examples for that could be destinations whose attractiveness is connected with a precise time of a year. Costal destinations whose main attractiveness is a sea, continental destinations whose dominant attractiveness are festivals or hunting or else. If intangible cultural heritage is well presented it is assumed that some tourists will consider coming to the destination out of the high season. This could be explained through different types of cultural tourists, respectively to which extent is culture important to them. Then again, some surveys showed positive results engaging cultural elements in the modification of seasonality. Cuccia and Rizzo (2011) have found that the contribution of cultural heritage in reducing tourism seasonality can be implied on destinations close to the sea.

The sevenths postulate implies that tourist valorisation of $\mathrm{ICH}$ increases tourist satisfaction. In all tourists traveling experience is the most important part. Experts and scholars are troubling with not just fulfilling tourist expectations but overcoming them. Each cultural good is different from another and special in some way. Arguing intangible cultural heritage that uniqueness is undeniable.

The postulates can be tested using the analysis of data gathered from tourists visiting destinations. Currently, we are not intending to report on the final results of the survey, since the research is still on-going. Nevertheless, it can be mentioned that a survey questionnaire was created and the pilot research was conducted on sample of 21 questionnaires. The main results show that most of tourists are young people between 19-29 years old (71.4\%), with education od high school (47.6\%). About $57 \%$ of respondents are currently studying and $38.1 \%$ are employed. Almost all of respondents are coming from EU countries (90.48\%). Roughly half of them are visiting Prague for the first time (52.4\%) and motives for the trip are mostly cultural tourism (42.9\%) and city brake (38.1\%).

However, none of respondents visited some place where they could learn about traditional production of Czech beer or glass, neither seen demonstration or taken part in one. Interesting is that $66.6 \%$ would definitely or most probably would like to have that kind of experience. In addition, $81 \%$ bought souvenir and that souvenir was related to Prague (81\%). $95.3 \%$ of respondents consider very important and important that souvenir represents local culture and $85.7 \%$ would definitely or most probably buy a souvenir that is produced in a traditional way although only $71.4 \%$ of them would buy a souvenir that is associated with Czech beer or glass. When asked if they could have a chance to learn about traditional production of Czech beer/glass would they stay longer in Prague answers were diversely distributed through five points of Likert scale with inclining toward negative answers (86.1\% of probably not or definitely no). In contrast $61.9 \%$ of respondents would definitely or most probably be willing to come out of the main/high season if they have an opportunity to learn about traditional crafts such as Czech beer or glass. Satisfaction of tourist in Prague in regard with cultural information and offer is quite high. $85.7 \%$ is very satisfied and satisfied with information about culture, $66.6 \%$ when it comes to intangible cultural heritage, and $95.2 \%$ is very satisfied and satisfied with offer of tangible cultural heritage. Satisfaction with offer of intangible cultural heritage is lower and uncertain $47.6 \%$ of respondents were not sure, $33.3 \%$ were satisfied, and $19 \%$ were dissatisfied. Tourists are more satisfied with tourist elements as accommodation, quality of food ( $90.5 \%$ is very satisfied or satisfied), tourist information in general ( $76.2 \%$ is very satisfied or satisfied). This can be caused by numerous reasons such as not enough information about intangible cultural heritage, information that is not clear enough, marketing affords are insufficient or inadequate or in the last case the lack of interest for proposed subject from the tourists. This can be cleared when the main research will be conducted.

\section{A Brief Comparison of the Cases of Croatia and the Czech Republic}

Croatia is a South-East European country with large number of cultural goods inscribed on the UNESCO list of world heritage. Both tangible and intangible cultural goods are represented here in great abundance (see Gračan et al., 2011). Moreover, the marine cultural heritage constitutes a very important asset (see Stipanović et al., 2012). Tangible cultural goods inscribed are the following (UNESCO, official website): Cathedral of Saint James, Episcopal Complex of the Euphrasian Basilica in the Historic Centre of Poreč, Historic city of Trogir, Historical Complex of town Split with the Palace of Diocletian, Old City of Dubrovnik, Plitvice Lakes National Park, Stari Grad Plain on island of Hvar (http://whc.unesco. 
org/en/statesparties/hr).

Intangible cultural goods are following (UNESCO, official website): Two-part singing and playing in the Istrian scale, Traditional manufacturing of Children's Wooden Toys in Hrvatsko Zagorje, Spring procession of Ljelje/Kraljice (queens) from Gorjani, Procession Za Križen (Following the Cross) on the island of Hvar, Lacemaking in Croatia, Festivity of Saint Blaise, patron saint of Dubrovnik, Annual carnival bell ringers' pageant from the Kastav area, The Sinjska alka, a knights' tournament in Sinj, Gingerbread craft from northern Croatia - Licitar, Ojkanje singing, Nijemo Kolo, silent circle dance of the Dalmatian hinterland, Bećarac singing and playing from Eastern Croatia, Klapa multipart singing of Dalmatia, southern Croatia, Mediterranean diet (Georgiev and Terziyska, 2013).

From the listed above it can be concluded that Croatia has a lot to offer when it comes to cultural tourism. However, in order to conduct a research on effects of intangible cultural heritage in tourism on sustainable development of cultural tourism these cultural goods were avoided. Author considered that marketing effects of UNESCO could interfere with real power of intangible cultural heritage and present bias results. Croatian Ministry of culture has s list of cultural goods that represent a local culture and have high value to the Croatian people and therefor takes care of each cultural good. From that national list five cultural goods were chosen to take part in the survey. The cultural goods were chosen in regard of geographical location in order to represent the parts of the whole country and different types of tourism that dominate the regions. The importance of the tourism industry for Croatia is great. Some of the recent research shows noteworthy contribution of the tourism industry to the GDP - the direct contribution is around 12\% and the total contribution is approximately $30 \%$. Tourism is supporting approximately $13 \%$ of the total employment and it accounts for more than a half of total exported services (Baldigara and Mamula, 2012).

The Czech Republic is central European country with rich history and many cultural elements that are serving as attractiveness factors for tourists (see e.g. Strielkowski, 2013; or Matušková and Strielkowski, 2014). According to the World Travel and Tourism Council, direct contribution of tourism to the GDP is around 2.9\%, and total around $8.8 \%$. Tourism is generates approximately $5 \%$ of total employment (WTTC, 2014). Czech Republic has several tangible cultural goods inscribed in the UNESCO's list of world heritage, such as (UNESCO, official website): Gardens and Castle at Kroměřžž, Historic Centre of Český Krumlov, Historic Centre of Prague, Historic Centre of Telč, Holašovice Historical Village Reservation, Holy Trinity Column in Olomouc, Jewish Quarter and St Procopius' Basilica in Třebič, Kutná Hora: Historical Town Centre with the Church of St Barbara and the Cathedral of Our Lady at Sedlec, Lednice-Valtice Cultural Landscape, Litomyšl Castle, Pilgrimage Church of St John of Nepomuk at Zelená Hora, Tugendhat Villa in Brno (http://whc.unesco.org/en/statesparties/CZ). Intangible cultural goods considered valuable to the whole human kind are (UNESCO, official website): Slovácko Verbuňk, recruit dances, Shrovetide door-to-door processions and masks in the villages of the Hlinecko area, Ride of the Kings in the south-east of the Czech Republic and Falconry, a living human heritage.

Again, in order to conduct non-bias survey the cultural goods were chosen: traditional production of Czech glass and traditional production of Czech beer. Both cultural goods are recognized by local community and well known among tourists.

Both countries are building heritage based tourism, having a rich background and long history of tourism. Implementing a new segment into tourist offer could bring benefits not just for the cultural element itself but for the whole tourism industry. Thence, they were chosen to examine the possible effects of intangible cultural heritage on sustainable development of tourism.

\section{Conclusions and Discussions}

The tourism industry is growing and becoming more and more significant in global context. In the same time, we are witnessing negative effects of tourism on many destinations. The idea of sustainable development has spread and entered tourism industry, as well. The future of tourist development will be based on principles of sustainability.

This paper proposed the idea of multiple effects on sustainable development of tourism based on introduction intangible cultural heritage into tourist offer of destination. Benefits could be observable on both, tourists and local community. The cultural goods chosen to take part in this survey are located in Czech Republic and Croatia. Both countries have been developing the tourism industry and have rich cultural heritage, as well. Several hypotheses have been formed and the pilot survey has been conducted.

The preliminary results our pilot study reveal the interest of tourists in the intangible cultural heritage, such as crafts, more specifically traditional production of Czech beer and glass. Tourist might stay longer if they had an opportunity to learn about traditional production of Croatian cheese and products of local crafts, or Czech beer and glass.

Moreover, it appears that they would be willing to pay for that kind of experience. Furthermore, most of the tourists 
we surveyed would buy a souvenir associated with Czech beer or glass. It might be concluded that intangible cultural heritage might have a positive effects on sustainable development of tourism, if it is adequately formed in the tourist cultural product.

Our results might be relevant for local tourism marketers and policy-makers, since they should take into account the potentials of $\mathrm{ICH}$ and its influence on the spending and the length of stay in case of international visitors and domestic tourists alike.

\section{References}

Baldigara, T. \& Mamula, M. (2012). Tourism Statistics in Croatia: Present Status and Future Challenges. Procedia - Social and Behavioral Sciences, 44, 53-61

Bramwell, B. \& Lane, B. (1993). Sustainable tourism: An evolving global approach. Journal of Sustainable Tourism, 1, 1-5.

Chiabai, A., Platt, S., \& Strielkowski, W. (2014). Eliciting users' preferences for cultural heritage and tourism-related e-services: a tale of three European cities. Tourism Economics, 20(2), 263-277

Choi, H. C., \& Sirakaya, E. (2006). Sustainability indicators for managing community based tourism. Tourism Management. 27(6), 12741289

Coccossis, H., 2008. Cultural heritage, local resources and sustainable tourism. International Journal of Services, Technology and Management, 10(1), 8-14

Cuccia, T. \& Rizzo, I. (2011). Tourism seasonality in cultural destinations: Empirical evidence from Sicily. Tourism Management, 32(3), $589-595$

Georgiev, G., Terziyska, I. (2013) Masterpieces of intangible heritage in the countries of southeast Europe and tourism development. Retrieved from: http://www.toknowpress.net/ISBN/978-961-6914-02-4/papers/ML13-407.pdf <accessed on 16.04.2015>

Gračan, D., Zadel, Z., \& Rudančić Lugarić, A. (2011). Four stars charter quality in charter service of Croatia. Naše more, Znanstvenostručni časopis za more i pomorstvo, 58(1-2), 64-73

Herget, J., Abrhám, J., \& Strielkowski, W. (2014). Success factors of growth and development for small and medium enterprises in tourism sector. Journal of Applied Economic Sciences, IX, 1(27), 101-109

Hughes, G. (1995) Authenticity in tourism. Annals of Tourism Research, 22(4), 781-803

Kurin, R. (2004). Safeguarding Intangible Cultural Heritage in the 2003 UNESCO Convention: a critical appraisal. Museum International, 56(1-2), 66-76

Lazano-Oyola, M. et al. (2012). Sustainable tourism indicators as planning tools in cultural destinations. Ecological Indicators, 18, 659675

Leask, A., \& Rihova, I. (2010). The role of heritage tourism in the Shetland Islands. International Journal of Culture, Tourism and Hospitality Research, 4(2), 118-129

Matušková, A., \& Strielkowski, W. (2014). Technology Applications in Czech Presidential Elections of 2013: A Story of Social Networks. Mediterranean Journal of Social Sciences, 5(21), 419-424

Rodzi, N. I. M., Zaki, S. A. \& Subli, S. M. H. S (2013). Between Tourism and Intangible Cultural Heritage. Procedia - Social and Behaviour Sciences, 85, 410-420

Sharareh, A. D., \& Badaruddin, M. (2013). Local Perception of Tourism Development: A Conceptual Framework for the Sustainable Cultural Tourism. Journal of Management and Sustainability, 3(2), 31-39

Steiner, C. J. \& Reisinger, Y. (2006). Understanding existential authenticity. Annals of Tourism Research, 33(2), 299-318

Stipanović, C., Gračan, D., \& Bradetić, M. (2012). The Development Concept in Function of the Competitiveness of Marina Frapa Rogoznica. Naše more, Znanstveno-stručni časopis za more i pomorstvo, 59(1-2), 61-69

Strielkowski, W. (2013). Mystery and thriller tourism: Novel solutions for European cities. Turizam: znanstveno-stručni časopis, 61(3), $277-287$

Strielkowski, W. (2014). Modelling the Impact of Infectious Diseases on Tourism. Applied Mathematical Sciences, 8(92), 4571-4577

Wang, N. (1999). Rethinking authenticity in tourism experience. Annals of Tourism Research, 26(2), 349-370

World Travel \& Tourism Council (2014). Travel \& Tourism Economic impact 2014 Czech Republic. Retrieved from: http://www.wttc.org//media/files/reports/economic\%20impact\%20research/country\%20reports/czech_republic2014.pdf <accessed on 15.04.2015>

WTO (2005). Facts \& Figures. Retrieved from: http://www2.unwto.org/facts/eng/vision.htm <accessed on 16.04.2015>

WTO (2015). Facts \& Figures. Retrieved from: http://www2.unwto.org/facts/eng/vision.htm <accessed on 16.04.2015>

Zhu, Y. (2012). Preforming heritage: rethinking authenticity in tourism. Annals of Tourism Research, 39(3), 1495-1513 